\title{
The Development of Problem-Based Stad Model to Improve the Writing Ability of Students in University
}

\author{
Wida Rianti, Mudjiran, Mukhaiyar
}

\begin{abstract}
This study is aimed to improve students' English writing skills in college. Since students' mastery of English vocabulary is still low, they are confused about the use of grammar, sentence structure, punctuation, good and correct spelling in English writing, making them unable to write well words/sentences/texts in English. Students also still have difficulty in terms of orderly expression of ideas and supporting sentences in paragraphs, and they have not been trained to develop ideas in writing properly and correctly. The type of research is development research or Research and Development (R\&D) with qualitative and quantitative approaches. The STADBM type learning model in this study has produced a valid, practical and effective model because it has an impact on improving students' writing skills and learning motivation.

Keywords: hybrid learning, quantum working, artwork practice.
\end{abstract}

\section{INTRODUCTION}

Argumentative writing skills are difficult to come by [20], [21], and the most difficult types of writing are [25], [26]. Students often produce incomplete arguments; they do not emphasize the element of argumentation; they don't write clearly; there is insufficient evidence to support the argument, and students may not understand or respond to other possible points of view [26], [6] suggesting that many students do not critique statements well and provide convincing support. The problem that most arises is the inability of students to make good declarative statements because they are not used to working with this writing and also they have insufficient knowledge to support their arguments in a real and clear way. Likewise, several studies suggest that student difficulties stem from grammar and lexical [20]. The success of argumentative writing is when the reader can be persuaded, brought, and conveyed to the paradigm put forward and believed by the author [55], [39], [43], [54], [56], and [63] are some researchers who are trying to overcome a difficulty in writing argumentative. [43] and [56] showed that the ability to write arguments can be improved by choosing effective strategies to stimulate students' writing skills. The research conducted by [63] used self-explaining as a method to improve argumentative writing skills focused on unstructured problems.

Revised Manuscript Received on December 05, 2020.

* Correspondence Author

Wida Rianti*, Doctoral Program Ilmu Pendidikan, Universitas Negeri Padang, Indonesia;

Mudjiran, Universitas Negeri Padang, Indonesia

Mukhaiyar, Universitas Negeri Padang, Indonesia

(c) The Authors. Published by Blue Eyes Intelligence Engineering and Sciences Publication (BEIESP). This is an open access article under the CC BY-NC-ND license (http://creativecommons.org/licenses/by-nc-nd/4.0/)
Through this method and using teaching about declarative knowledge and connected with argumentation, it can lead to students' argumentative production. Research in Pamulang shows that writing errors in learning writing are still high, regular verbs $58.3 \%$ and irregular verbs reaching $41.70 \%$ [28]. Research findings [32] show that to develop English writing skills, among the 10 teachers interviewed, $30 \%$ gave 25 to 30 minutes, $20 \%$ gave 15 minutes just to brainstorm. Only $10 \%$ gave 40 minutes, and $40 \%$ gave no time to write at all.

[18] categorized three problems that make writing skills difficult to master, namely linguistic problems (our shrewdness in writing the correct structure), cognitive (related to language forms, structures, grammar), and content (related to ideas). [29] mentioned a very large emphasis on grammar aspects, excessive emphasis on final results in writing, less emphasis on genre-specific writing across the curriculum, and a lack of diversification of feedback are some problems encountered in learning to write in English. Several studies have shown that students' ability to speak English is still weak [20]. The students stated that their mastery of English vocabulary was still low; they were confused about the use of grammar, sentence structure, punctuation, good and correct spelling in English writing, making them unable to write well words/sentences/texts in English. Students also still have difficulty in terms of orderly expression of ideas and supporting sentences in paragraphs, and they have not been trained to develop ideas in writing properly and correctly. The results of the observations also show that the lack of lecturers' preparation in preparing learning tools before learning, unclear learning outcomes formulas, and unclear learning strategies and methods used are seen in teaching English.

\section{METHODOLOGIES}

The type of research is development research or Research and Development (R\&D) with qualitative and quantitative approaches. This research was conducted using the ADDIE model. The research data were taken in the English Language Study Program at Pahlawan Tambusai University. The data analysis of this research was carried out using descriptive statistical analysis techniques and descriptive techniques. Descriptive statistics to analyze student learning outcomes and English skills tests, observation sheets, and questionnaires. While the descriptive technique is to analyze the results of interviews, analysis, and field notes.

Published By:

Blue Eyes Intelligence Engineering \& Sciences Publication

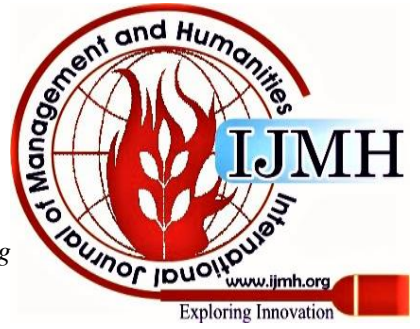




\section{RESULTS ANALYSIS}

\subsection{Product Validity}

Validation of the model is carried out by looking at three aspects, namely aspects of graphics, language, and learning. The three aspects that are judged to get a B value, which can be used with a few revisions. Revisions are carried out according to expert suggestions.

The expert judgment shows that in general the model book that has been carried out has met the valid category Suggestions from experts are very necessary for the development of a model that is carried out to suit the rational as well as the characteristics and theoretical basis that support. The rational model presented by the model book reveals the importance of developing a Learning Model Type STAD-BM. STAD is a simple collaborative learning model where small groups of students with various levels of ability work together starting with the presentation of objectives, the presentation of material, the discussion of quizzes, and team achievements [22], [36]. The components in the model were developed according to opinion [37] which includes syntax, reaction principles, social systems, support systems, and instructional impact. The STAD-BM type of learning model is supported by supporting theories such as behaviorism learning theory based on opinion [65], where Skinner makes strengthening the heart of learning and lecturers provide reinforcement to students to obtain the desired behavior. Another theory is cognitivism, which in this case is focused on constructivism. [49] argued about the constructivism approach that is successfully applied in writing learning. Lecturer books contain learning tools and material taught. Therefore, the expert assessment of lecturers' books is carried out on four aspects, namely aspects of graphics, language, learning, and content. The results of expert assessments of lecturers' books in these four aspects belong to the $\mathrm{B}$ value interval, which can be used with a little revision. The revisions used, among others, relate to sentences, book size, and clarity of steps for activities carried out in learning and content that supports the STAD-BM Type Learning Model. Lecturer books contain lecturer activities in learning which are compiled based on the STAD-BM Type Learning Model. As an educator, lecturers must be able to carry out learning to increase students' knowledge and be able to improve their social skills. In accordance with the opinion [69], in this model, the lecturer gives group rewards, controls students to be individually responsible for completing assignments, and ensures collaboration runs well in small groups. The aspects assessed in the validation of student books are the same as those assessed in lecturers' books, namely graphics, language, learning, and content. The difference is, there are syllabus and lesson plans in lecturers' books, while the student books are not published. The results of expert assessments of student books are classified as category B grade intervals, can be used with a little revision. Revisions are carried out according to expert advice. Revisions were made to make this book easier for students to understand the material being studied. Based on the results of the discussion of the results of the validity test of the Learning Model Type STAD-BM, it can be concluded that the model book, lecturer book, and student book are suitable for use. The validation carried out by these experts was classified as consistent, which was supported by the results of the SPSS output, where the ICC value was 0.786 . This is in accordance with the opinion [1999] that the learning model is said to be valid if the model development is in accordance with the procedure and is based on the field of knowledge and the theory of developing teaching materials. Expert judgment is supported by the implementation of formative evaluation proposed by Tessmer (in Plomp 2013) that the product that has been validated by an expert has a better resistance level compared to other techniques. [2] argued that validity refers to the level of intervention design based on state of art knowledge and various components of the intervention related to one another. Rochmad (2012) states that the learning model developed is said to be valid if the model is based on adequate theory (content validity). ) and all components of the learning model are consistently related to each other (construct validity).

\subsection{Product Practicality}

The practicality test of the STAD-BM Type Learning Model is seen from three aspects, namely (1) practicality according to the lecturer, (2) practicality according to students, and (3) practicality seen from the implementation of the STAD-BM Type Learning Model. The practicality test according to students was carried out in the one-to-one evaluation stage, small group to field testing, where the questionnaire was filled out by students who were involved in testing the product of this research. Two students who were involved in the one-to-one evaluation stage gave an assessment of $90.63 \%$ which was classified as the very practical category. However, there were several points of suggestion that were conveyed directly by students as input in product improvement. The practicality test results at the small group stage obtained a score of $92.08 \%$ which is classified as very practical. This means that five students who were involved in the small group evaluation stated that the product could be understood by students, even though there were several suggestions that were submitted by students for product improvement. The practicality test at the field test stage involving 20 students showed that the practicality score was $90.10 \%$, which was classified as very practical. The highest score is only in the graphic element, while the use element still needs to be improved because the student response is mostly still below $90 \%$. The practicality test according to the lecturer was carried out at the field test stage, where there were two lecturers of the English Language Study Program at Pahlawan Tuanku Tambusai University who were involved in this research. Two lecturers argued that in general the model developed was practical, with a score of 87.5. There are 10 aspects that were scored by the lecturer, including ease of use, the suitability of time, readability, and attractiveness. In general, no score is too low, but there are two points that still need attention, namely the allocation of time and the level of difficulty of the assigned task. The implementation of the STAD-BM Type Learning Model is classified as very practical. The lowest score is in the activity of guiding individual and group investigations, which is $85 \%$, which means that lecturers need to evaluate the role that has been played in implementing the STADBM Type Learning Model to make it even better.

Published By:

Blue Eyes Intelligence Engineering \& Sciences Publication 
The development result model is said to be practical if it has a level of implementation that is in the good category by seeing whether the model components can be implemented in learning. Observations were carried out focused on the syntax whether it was carried out fully by the lecturer, the component of the reaction principle that was applied occurred in classroom learning, the supporting system components supported the smoothness of learning. [2] revealed that practicality refers to the degree that the user considers an intervention to be used and preferable under normal conditions.

[50] measuring the level of practicality seen from whether the lecturers and other experts consider that the material is easy and can be used by lecturers and students. The results of this study are relevant to research conducted by [72] through the STAD learning model, students' ability to write descriptive was increased. The STAD-BM type learning model produced in this study is also supported by previous research on the role of PBL in learning English in the classroom to improve writing skills. The difference is, in this study, the model used is a combination of the STAD Type model with Problem Based Learning which is used as the STAD-BM Type Learning Model.

\subsection{Product Effectiveness.}

The results of the effectiveness of the model are seen from the increase in the instructional impact component and the accompanying impact of the development of the STAD-BM Type Learning Model. The instructional impact of the STAD-BM Type Learning Model is the student's writing ability. While the accompanying impact is student learning motivation. Based on calculations using the different tests, it is known that there is an increase in student writing skills after the application of the STADBM Type Learning Model compared to before the application of the STAD-BM Type Learning Model. The grammar element is still a fundamental issue that needs to be improved, because in writing good and correct paragraphs, the element of truth in terms of grammar is the main requirement. However, the neatness and layout of the writing must also be considered, because good writing is also seen from the neatness of the appearance of the writing. As stated by [17] that in writing mechanism elements, grammatical accuracy, writing style, and ease and comfort in expressing writing need to be a concern. Therefore, vocabulary problems, language use, and writing techniques are very important in writing, [79]. The accompanying impact in this study has increased. Students become more motivated to learn because they feel challenged to solve problems of daily life. When viewed in terms of criteria, the motivation scores before and after the application of the STAD-BM Type Learning Model are both classified as moderate. However, statistically descriptive, there was an increase in the average motivation score, and the results of different tests showed that there were significant differences in motivation before and after the application of the STADBM Type Learning Model. The effectiveness of the developed model refers to the degree to which the experience and results of the intervention are consistent with the goals achieved. [50] measuring the level of effectiveness of the student's reward level in studying the program and students' desire to continue using the program. [59] revealed that the model is said to be effective can be seen from the writing ability and learning motivation of students.
The results of the effectiveness of this study are in line with the opinion [67] that the STAD Type model is a model designed so that students become more motivated in understanding learning material. [81] in his research revealed the impact of the Type STAD model based on Social Media in the form of self-actualization, motivation, independence, and collaboration. [5] found that the STAD model was able to improve students 'English skills. The findings [48] showed that the STAD model was effective in teaching short stories (reading) in English learning. This model was able to improve students' mastery of short stories and also help improve students' interest in reading learning. [24] found that students who used the STAD model in learning made significantly higher progress in reading comprehension. Problem-based learning models have also been shown to improve students' academic achievement. [51] found that PBL was able to improve students' writing skills in learning English. [11] found that PBL was able to improve students' problem-solving abilities and make students motivated in learning. [41] also found that the PBL learning model was able to improve students 'vocabulary mastery. The STAD-BM type learning model in this study produced an effective model because it had an impact on improving students' writing skills and learning motivation.

\section{CONCLUSION}

This research is a research and development of the STAD-BM Type Learning Model and the system/product support model in the form of lecturers and student books. Based on the discussion of the research results, it can be concluded that 1) the STAD-BM Type Learning Model has been produced through the ADDIE development model. 2) Learning Model Type STAD-BM which has met the criteria of validity, practicality, and effectiveness. The model is said to be valid with the characteristics of the suitability of the research model development with the ADDIE procedure. The model is said to be practical with the characteristics of ease of use, time suitability, language readability, attractiveness, and feasibility of each phase in the model. The model is said to be significantly effective proven to be able to improve writing skills and student motivation.

\section{ACKNOWLEDGMENT}

Thanks to the lecturer promoter, Prof. Mudjiran and Prof. Mukhayar. Their guidance and attention were both extraordinary so that this paper could be completed. Thank you also to the entire academic community of Padang State University.

\section{REFERENCES}

1. Abidin.2014. Desain Sistem Pembelajaran dalam Konteks Kurikulum 2013. Bandung: Refika Aditama.Hadijah, Sitti. 2014. Investigating the Problems of English Speaking of The Students of Islamic Boarding School Programat Stain Samarinda. Dinamika Ilmu. Vol. 14. No 2 .

2. Akker, J. Van den. 1999. Principles and Method of Development Research. London. Dlm. van den Akker, J., Branch, R.M., Gustafson, K., Nieveen, N., \& Plomp, T. (pnyt.)". Design approaches and tools in educational and training .Dordrecht: Kluwer Academic Publisher.
Blue Eyes Intelligence Engineering \& Sciences Publication

(C) Copyright: All rights reserved.

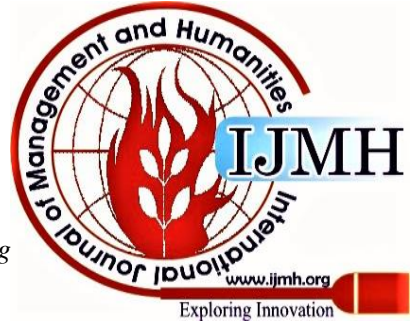


3. Alabi, V.A, \&Babatunde. 1998. The Use of English in Higher Education. Nigeria: Ilorin University Press.

4. Alameddine, M. (2012).Teaching Business English for Arab Speakers.American Academic and Scholarly Research Journal, 4(4).

5. Alijanian, Ehsan. 2012. The Effect of Student Teams Achievement Division Technique on English Achievement of Iranian EFL Learners. Theory and Practice in Language Studies, Vol. 2, No. 9, pp. 1971-1975.

6. Amogne D (2013). Enhancing students ' writing skills through the genre approach. Int. J. English Lit. 4(5):242-248.

7. Arends, Richard. 1997. Classroom Instructional Management. New York: The McGraw-Hill Company.

8. Arends, R. I. 2007. Learning to TeachingBelajar untuk Mengajar Pustaka Pelajar: Yogyakarta.

9. Arikunto, S. 2007. Dasar-Dasar Evaluasi Pendidikan. Jakarta: PT. Bumi Aksara. 2012. Prosedur Penelitian: Suatu Pendekatan Praktek. Jakarta: Rineka Cipta.

10. Argaw, Aweke Shishigu, dkk. 2017. The Effect of Problem Based Learning (PBL) Instruction on Students' Motivation and Problem Solving Skills of Physics. EURASIA Journal of Mathematics Science and Technology Education. Vol. 13(3): p. 857-871.

11. Baker, Jack. dkk. Argumentative essay (https://owl.english.purdue. edu, Diakses pada tanggal 13 Juli 2019).

12. Barret, Terry. 2006. Understanding Problem Based Learning. [online] Tersedia: https://www.researchgate.net/publication/242683636.

13. Barrows, S. H \& Tamblyn, R. M. 1986.Problem Based Learning An Approach Medical Education. Spirnger Publishing Company : New York.

14. Borg, W.R, Gall, M.D, \& Gall, J.P. 1989. Educational Research an Introduction.New York: Pearson Education.

15. Branch, Robert M. 2009.Instructional Design : The ADDIE Approach. New York. Springer Science Business Media.LLC.

16. Broughton, Geoffrey. 1980. Teaching English as foreign language. London: Rouledge.

17. Byrne, Donn. 1988. Teaching Writing Skills. London and New York: Longman.

18. Butler, Y. G. 2005. Comparative perspectives towards communicative activities among elementary school teachers in South Korea, Japan and Taiwan.Language Teaching Research, 9, 423-446.

19. Chanie, S. B. (2013). "Conceptions about Language Syllabus and Textbook Based Instructions: TEFL Graduate Students in Focus". Online Jurnal of Education Research. (2), 66-71. Available Online at http://www.onlineresearchjournals.org/IJER

20. Deane P, Song Y (2014). A case study in principled assessment design: Designing assessment to measure and support the development of argumentative reading and writing skills. Psicología Educativa, 20(2):99-108.

21. Deswarni, Dini. 2018. The Effect of Using Stad Strategy Toward Students' Reading Comprehension. Al-Ishlah.Jurnal Pendidikan. Vol. 10, No. 1.

22. Douglas, C, \& Morris, S.R. 2014. Student Perspective on Self Directed Learning. Journal of the Scholarship of Teaching and LEarnig, 14(1), 13-25.

23. Faramarz, Sepideh, \& Bahram Mowlaie. 2017. The Effect of Using the Student Teams Achievement Division (STAD) Technique on Improving Iranian Elementary EFL Learners' Reading Comprehension. Journal of Applied Linguistics and Language Research. Volume 4, Issue 3, 2017, pp. 51-64.

24. Ferretti RP, MacArthur CA, Dowdy NS (2000). The effects of an elaborated goal on the persuasive writing of students with learning disabilities and their normally achieving peers. J. Educ. Psychol. 93:694-702.

25. Ferretti RP, Andrews-Weckerly S, Lewis WE (2007). Improving the Argumentative Writing of Students with Learning Disabilities: Descriptive and Normative Considerations. Reading \& Writing Q. 23(3):267-285

26. Gomleksiz, M. N., \& Elald, S. 2011. Foreign language teaching in the context of constructivist approach. Turkish Studies International Periodical for the Languages, Literature and History of Turkish or Turkic, 6(2), 443-454.

27. Hadijah, Sitti. (2014). Investigating the Problems of English Speaking of the Students ff Islamic Boarding School Program at STAIN Samarinda. Dinamika Ilmu, Vol 14 No 2, 2014

28. Hà, Trần Thu. 2011. Thesis. Integrating Reading and Writing Teaching to Improve VNUH-ULIS First Year English Majored Students' Writing Skills".University of Languages and International Studies.

29. Hamdani. 2011. Strategi Belajar Mengajar. Bandung : Pustaka Setia.
30. Herliwati. 2011. Thesis. Error Analysis in the Studens Writing Narrative Paragraph at Mtsn Pajajaran Pamulang. Jakarta: State Islamic University Syarif Hidayatuallah.

31. Hidayati, Kuni Hikmah. 2018. Teaching Writing to EFL Learners: An Investigation of Challenges Confronted by Indonesian Teachers. LANGKAWI Journal.4(1): 21-31.

32. Ho, W. K. 2003. English language teaching in Asia today: An overview. In W. K. Ho\& R. Y. L. Wong (Eds.).English language teaching in East Asia today: Changing policies and practices (pp. 132). Singapore: Eastern Universities Press.

33. Ho, B. 2011. Solving The Problems of Designing and Teaching a Packed English for Specific Purposes Course. New Horizon in Education, 59(1).119-136.

34. Iskk, A. 2008. Where Do Wrongs in Our Foreign Language Education Stem From?.Journal of Language and Linguistics, 4(2), 15-26.

35. Istarani. 2012. 58 Model Pembelajaran Inovatif. Medan: Media Persada.

36. Joyce, W \& Weil, M. 2003.Models of Teaching (Fifth-Edition).New Delhi: Prentice-Hall of India Private Limited.

37. Joyce, Marsha Weil, Emily Calhoun. 2011. Models of Teaching, Edisi 8. Yogyakarta: Pustaka Belajar.

38. Ka-kan-dee M, Kaur S (2015). Teaching Strategies Used by Thai EFL Lecturers to Teach Argumentative Writing. Procedia - Social and Behavioral Sciences (Vol. 208). Elsevier B.V.

39. Kemendikbud. 2013. Kerangka Dasar Kurikulum 2013. Kementerian Pendidikan dan Kebudayaan Direktorat Jenderal Pendidikan Dasar. Jakarta.

40. Kimsesiz, Fatma, dkk. 2017. The Effect of Project Based Learning in Teaching EFL Vocabulary to Young Learners of English: The Case of Pre-school Children. International Journal of Languages' Education and Teaching. Volume 5, Issue 4, p. 426-439.

41. Klegeris, A, \& Hurren, H. 2011. Impact of Problem Based Learning in Large Slassroom Setting: Student Perception and Problem Solving Skills. Advances in Physiological Education 35(4), 408-415.

42. Lertpreedakorn, N. (2009).Genre-based Approach to Teaching Academic Writing. In A. M.Stoke (Ed.), JALT 2008 Conference Proceedings. Tokyo: JALT.

43. Liu, Min. 2005. Motivating Students Through Problem-based Learning. University of Texas : Austin. [online]. Tersedia: https://authorzilla.com.

44. Meyer, R.E. 2004. Review of Educational Research. New York: McMillan.

45. Miao, Yongwu et.al. (-).PBL-protocols: Guiding and Controlling Problem Based Learning Processes in Virtual Learning Environment. GMD : Darmstad. [online]. Tersedia: https://www.researchgate.net/publication/2635026 PBLprotocols_Guiding_and_Controlling_Problem_Based_Learning_Proc esses_in_Virtual_Learning_Environments.

46. Nababan, P.W.J. 2984. Indonesia: The Language Situation. Dalam Richard B. Noss (Ed). Language Teaching Issues Multilingual Environments in South East Asia. Hal: 1-47. SEAMO Regional Language Center: Singapore.

47. Nair, Subadrah Madhawa, \& Chee Peck Kim. 2014. The Effects of Using the STAD Method in Teaching the Short Story, Flipping Fantastic on Form One Students. IPEDR, vol.81.

48. Neale, Stephen (1990). Descriptions. Cambridge MA: MIT Press.

49. Nieveen, N. (1999). Design Approaches and Tools in Education and Training. Springer Science Bussines Media, B.V. DOI. 10.1007/97894-011-4255-7.

50. Othman, Normala \& Mohamed Ismail Ahamad Shah. 2013. ProblemBased Learning in the English Language Classroom. English Language Teaching; Vol. 6, No. 3.

51. Ozagac, Oya. Argumentative Essay, (Www.buowl.boun.edu,tr, Diakses pada tanggal 13 Juli 2019).

52. Paker, T. 2007. Problems of Teaching English in Schools in Cal Region and Suggested Solutions. 21. Yuzylla Girerken Gecmisten Gunumuze Cal Yoresi: Cal Yoresi Yardimlasma ve Dayanısma Dernegi Yayını, 3, 684-690.

53. Panahandeh E, Esfandiari S (2014). The Effect of Planning and Monitoring as Metacognitive Strategies on Iranian EFL Learners' Argumentative Writing Accuracy. Procedia Soc. Behav. Sci. 98:14091416.

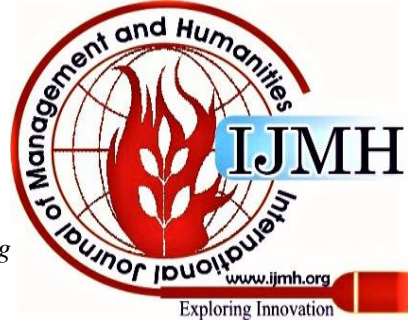


54. Pranowo (2000). Pembelajaran Menulis Argumentasi" Strategi Pembelajaran Bahasa dan Sastra Indonesia di Sekolah Berdasarkan Pendekatan Komunikatif. (A. M. S. Soewandi, Y. Setiyaningsih, \& Y. F. S. T. Nugraha, Eds.). Yogyakarta: Universitas Sunata Darma.

55. Promwinai, P.(2010). The Demands of Argumentative Essay Writing: Experiences of Thai Tertiary Students.(Doctor of Education),University of Wollongong. Retrieved August10, 2013 from http://ro.uow.edu.au/theses/3298

56. Purwanto, Ngalim. 2009. Prinsip-Prinsip dan Teknik Evaluasi Pengajaran. Bandung: PT Remaja Rosdakarya.

57. Rezai, A., Rahimi.M. A, \& Talepasan, S. 2012. Exploring EFL Learners Reading Comprehension Problems in Readig ESP Texts.Sino-US English Teaching, 9(3).982-987.

58. Rochman, Syaifur. 2002. Contextualizing Communicative Language Teaching or Adult Japanese Learners. Jurnal Pendidikan dan Pengajaran IKIP Negeri Singaraja, No. 4, hal: 129-139.

59. Rusman. 2014. Model-Model Pembelajaran, Mengembangkan Profesionalisme Guru. Jakarta: PT Raja Grafindo Persada.

60. Saeed, Nada Rashid, \& Fatima A.A dan Jafar. 2016. Problems of Teaching English in Iraqi Public Schools in Mosul for the Intermediate Stage from the Teachers' Point of View. International Journal of Humanities and Social Science.Vol. 6, No. 1.

61. Sanjaya, Ade. 2011. Model-model Pembelajaran. Jakarta: Bumi Aksara.

62. Schworm, S., \& Renkl, A. (2007). Learning argumentation skills through the use of prompts for self-explaining examples. Journal of Educational Psychology, 99(2),

285296. https://doi.org/10.1037/0022-0663.99.2.285

63. Shamim, F. 2012. Teaching large classes.In A. Burns \& J. C. Richards (Eds.), The Cambridge guide to pedagogy and practice in second language teaching. New York, NY: Cambridge University Press.

64. Skinner, B. F. (1953). Science And Human Behavior. Macmillan. New York

65. Slavin, R.E. 1995. Cooperative Learning: Theory, Research and Practice (2nd Edition). Massachusatts: Allyn and Bacon publisher.

66. Slavin, R. E. 1994.Student teams achievement divisions. Handbook of cooperative learning methods. Westport, CT: Greenwood.

67. 1995. Cooperative learning: Theory, research, and practice. Englewood Cliffs, NJ: Prentice-Hall.

$68 . \quad$ 2009. Cooperative Learning Teori, Riset, dan Praktik Bandung: Nusa Media.

69. Sudijono, Anas. 2012. Pengantar Statistik Pendidikan. Jakarta: Rajawali Press

70. Sugiyono. 2011. Metode Penelitian Pendidikan (Pendekatan Kuantitatif, Kualitatif, dan R\&D). Bandung: Alfabeta.

71. Suzani, S. M, Yarmohammadi, L. \& Yamini, M. 2011. A Critical Review of The Current Situation of Teaching Esp In the Iranian Higher Education Institutions. The Iranian EFL Journal, 7(6).179-204.

72. Tabatabaei, Omid, \& Ali A. Pourakbari. 2012. An Investigation into the Problems of Teaching and Learning English in the Isfahan Province High Schools, Iran. Journal of Language Teaching and Research, Vol. 3, No. 1, pp. 102-111.

73. Tan, Oon-Seng. 2004. Cognition, Metacognition, and Problem-Based Learning, in Enhancing Thinking through Problem-based Learning Approaches. Singapore: Thomson Learning.

74. Trianto, 2010.Model Pembelajaran Terpadu. Jakarta: Bumi Aksara.

75. Unal, Menderes, \& Elif Ilhan. 2017. A Case Study on the Problems and Suggestions in Foreign Language Teaching and Learning at Higher Education. Journal of Education and Training Studies Vol. 5 , No. 6.

76. Walpole, Ronald E. 1995. Pengantar Statistika. Jakarta: PT Gramedia Pustaka Utama.

77. Wedgwood, R. 2007. Education and poverty reduction in Tanzania.Journal of Educational Development, 27, 383-396.

78. Weigle, Sara Cushing. 2002. Assessing Writing. Cambridge: Cambridge University Press.

79. Widoyoko, Eko Putro. 2009. Evaluasi Program Pembelajaran Yogyakarta: Pustaka Pelajar.

80. Wijaya, Hengki, \& Arismunandar.2018. Pengembangan Model Pembelajaran Kooperatif Tipe STAD Berbasis Media Sosial.Jurnal Jaffray. Vol. 16, No. 2: 175-196.

\section{AUTHOR PROFILE}

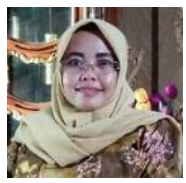

Wida Rianti, She is Lecturer in Pahlawan Tuanku Tambusai University. Her educational history includes S1 English education is Bung Hatta Padangg, Magister English Education Padang State University. Her scientific publications are Key issue in EFL autonomus learning Journal of English language education 2 (1) vol: 1 issue/2018, Improving student learning outcomes of English by using role playing at sdn 022 Rumbio Jurnal of English language education 2 (2) vol 2: issue/2018, Increase the ability to recognize numbers through numeric games in early childhood, Obsession journal: early childhood journal (2) vol: issue/2016, Students' mathematical representation ability to complete the pisa / 2015 questions Scholarly Journal: Mathematics Education Journal (2) vol 1 issue/2018, The efffect of using mind mapping on the writing comprehension ability of thr eleventh grade students at smkn 1 kuok in the academicyear 2019Journal of english learning education vol 1 issue 2019, Improving students writing skills in english lesson with action learning strategies at tenth grade of SMA 1 Bangkinang.

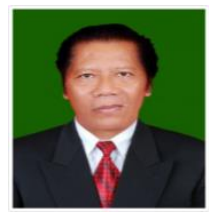

Prof. Dr. Mudjiran, MS, Kons He is a professor with an expertise in counseling. Mudjiran counselors are active consorers and currently also work as teaching staff in the Department of Counseling, Padang State University. His educational history includes S1 Counseling Guidance, graduating in 1976 at IKIP Yogyakarta. Masters in Educational Psychology graduated in 1988 at Gajah Mada University. S3 Education Science graduated in 2010 at Padang State University. Some of the young articles include the impact of pornography on student behavior and the efforts of supervisors to overcome it, the relationship between game addiction and student learning motivation and its implications for guidance and counseling, the contribution of self-concept and parental support to student learning motivation and its implications in guidance and counseling services, conceptual relationships. student self with student social behavior, early mental recovery of the community after the earthquake in the city of Padang.

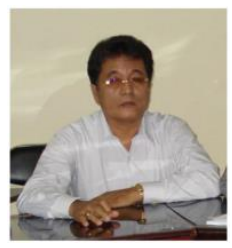

Prof. Dr. Mukhaiyar, M.Pd He is a professor at the Faculty of Language and Arts, Padang State University. he was born on 12 June 1950 in Agam. He has written a number of articles, namely the Study of Curriculum Organizational Study Programs in the Electrical Engineering Department of UNP as a policy reference for other LPTK Universities, English as a second language for an international nursery student in the United Kingdom, the need for aunthenthic assessment for speaking skills at junior high school, the effect of using insert strategy and motivation on the reading comprehension of the second grade students of SMPN 11 Sijunjung West Sumatra, students 'need for teaching materials to write articles in English based on criteria of reputable journals, students' writing descriptive text ability in relation to their personality types case study: second grade students of MAN/MAKN Koto Baru Padangpanjang.

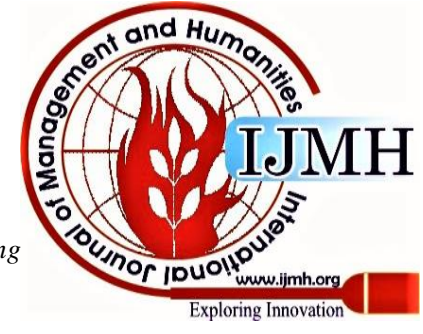

